\title{
Hiding the unwanted: A University-level campus carry policy
}

\section{Sampo Ruoppila ${ }^{1}$}

Accepted: 9 July 2021 / Published online: 11 August 2021

(C) The Author(s) 2021

\begin{abstract}
Campus carry laws have allowed civilians to legally bring their concealed firearms onto college and university campuses in several states in the U.S. over the past decade. Previous studies have addressed the policy's legal grounds, arguments for and against it, impacts on campus safety, and faculty and students' attitudes toward it. This paper examines the less addressed topic of policy implementation, especially the role of universities in modifying the outcomes, including what kinds of rules the higher educational institutions themselves have designed and what these approaches mean. The article focuses on Texas, where public higher educational institutions were required to allow campus carry but also given some discretion in implementation. The article provides a qualitative content analysis of policy documents and expert interviews regarding the campus carry policy at The University of Texas at Austin. It argues that the university fully accomplishes the law, but through its policy it has also sought to hide it, removing the issue from everyday life on campus.
\end{abstract}

Keywords Campus safety $\cdot$ Campus carry $\cdot$ Public policy $\cdot$ University policy $\cdot$ Policy implementation

\section{Introduction}

As society changes, universities are required to change, too. This can mean the adoption of policies that appear at odds with their primary remit as a realm of academic scholarship and higher learning. Recent reforms of U.S. gun laws have forced public higher education institutions in ten states to accepthowever reluctantly — that faculty, staff, and students are legally permitted to carry a concealed firearm can also do so on university premises. Moreover, universities have been required to define their campus gun policies. The article focuses on Texas, where public higher educational institutions were required to allow concealed carry on campuses but given some discretion in implementation.

Sampo Ruoppila

sampo.ruoppila@utu.fi

1 Department of Social Research, University of Turku, Turku, Finland 
The United States has experienced a major deregulation of firearms since the 1980s, both in terms of who can carry guns and where (Spitzer, 2015; Winkler, 2011). Reinterpretation of the Second Amendment has been at the core of this change, allowing people more rights to possess and publicly carry a firearm for the purpose of self-defense (Arrigo \& Acheson, 2016). In many states, "may-issue laws," which require a demonstrated and specific need to justify a license to carry, have been replaced by "shall-issue laws," which require authorities to provide a license - without discretion - to any applicant who meets the established criteria. For years, the license to carry referred primarily to concealed handguns, but recently many states (Texas included) have also allowed license holders to open carry (wearing a gun in full view) except in certain restricted areas. By July 2021, 21 states had even supported constitutional carry, where a handgun can be carried legally, either openly or concealed, without any license or permit. In Texas, such a bill will take effect on September 1, 2021 (Sparber, 2021). Nonetheless, all states that allow individuals to carry handguns on campuses only allow concealed carry there.

Already before the recent wave of deregulation, the United States had a prevalence of gun ownership, limited restrictions on buying guns, and legal acceptance of the use of deadly force to defend oneself. In a national survey conducted in 2017, 30\% of Americans reported that they currently owned a gun, while altogether $42 \%$ lived in a household with a gun (Pew Research Center, 2017). The very high rate is partly explained by most states not requiring any permit to purchase a gun or gun owners to hold a license. Moreover, many states apply some version of a "castle doctrine," which designates a person's home or vehicle as a place in which force (including lethal force) is permitted, in certain circumstances, in order to defend oneself against an intruder. The laws reinterpreting the Second Amendment have effectively expanded people's right to defend their home and possessions without having to retreat (Boots et al., 2009). Whether because of legal changes, rising fear, or a decline in other uses, "protection" has become the biggest motivation to own a gun (68\%), over hunting (38\%) - a major difference since 1999 (Pew Research Center, 2017). The number of licenses issued to civilians to carry a handgun in public has also seen a steep rise (Lott \& Wang, 2020). Approximately 1 in $13(7.6 \%)$ of the total adult population of the U.S. had a handgun permit by 2019 (ibid.). Moreover, at that time, 17 states no longer required a permit to carry in all or virtually all of the state, and therefore did not provide new statistics anymore (ibid.). In Texas, where a permit was required, $7 \%$ of the adult population had one (Lott \& Wang, 2020). Overall, the emphasis of U.S. gun culture has shifted to armed self-defense, or what Yamane (2017) calls "the armed citizenship."

Campus carry laws, which allow civilians to legally bring their concealed firearms into public college and university buildings, have now been passed in ten states-Arkansas, Colorado, Georgia, Idaho, Kansas, Mississippi, Oregon, Texas, Utah, and Wisconsin-and they are pending in a few others (National Conference of State Legislatures, 2019). According to Johnson and Zhang (2020), common for these states were Republican legislatures in state government, conservative citizen ideology, anti-gun-control interests, that neighboring states had also introduced campus carry bills, and that active shooting incidents (though not necessarily on campuses or at schools) had occurred in the year prior to enactment. An additional 23 states have granted the right to individual colleges or universities to decide whether to ban or allow concealed carry on their campuses (National Conference of State Legislatures, 2019). Campus carry legislation has moved forward and gained ground nationally in spite of appalled and opposing opinions and statements by those in the higher education community (e.g., Harnisch, 2008), including campus police forces (Chase, 2015). 
In a society where firearms are increasingly approved, the dispute over campus carry boils down to the question of whether concealed handguns should be allowed without restrictions or whether some "specific places" should be excluded on the basis of their population and the activities conducted there. A U.S. Supreme Court decision (District of Columbia v. Heller, 2008) that has been crucial in the reinterpretation of the Second Amendment recognized educational institutions, including university and college campuses, as public sites where bans on weapons may exist. Therefore, it is only in states where the legislature has imposed campus carry that public higher educational institutions have not succeeded in continuing bans (Arrigo \& Acheson, 2016). Where the decision has been left to higher educational institutions themselves, including private colleges and universities in campus carry states, the overwhelming majority have continued to prohibit concealed carry on their campuses. In Texas, for instance, only one private university (oriented toward adults and not having a physical campus) allows campus carry; all others have opted out (Watkins \& Conway, 2016).

To date, the scholarly work on campus carry as policy has summed up the central arguments for and against it, discussed the implications for public health, and examined the attitudes of faculty, students, and staff. However, there is much less research on implementation, including the agency of universities. Texas has been a point of special interest, as the law there emphasizes the role of universities in implementation. The Texas legislation requires all public universities to allow concealed carry, but it also empowers each university to draw up their own meaningful firearms policy, even including identification of limited campus-specific gun-free zones (Short, 2019, 445-456).

This study contributes by focusing on the universities' role in further defining the policy through implementation. It examines how one major state university, The University of Texas at Austin (henceforth UT Austin), designed its implementation, and offers an interpretation of the policy content and its implications. The paper argues that with the leeway offered by the Texas legislature, it established a policy that accomplished the letter of the law but also aimed to play down the issue in everyday campus life.

\section{Perspectives on campus carry policy}

While permitting campus carry has essentially been motivated by a wish to advance gun rights, many authors connect the policy with the fear of a malicious intruder, "the active shooter," and the idea — or right—of armed self-defense as a response. A watershed event that evoked such fears was the mass shooting at Virginia Tech (2007), which unleashed "a torrent of proposed state legislation" to "permit more guns on campus in the belief that an armed community would serve as a deterrent to violent crime" (Birnbaum, 2013, 8). While U.S. college and university campuses are not immune to crime and violence (including forcible sex offenses and aggravated assault, but seldom homicide), studies have confirmed that on average they are very safe places; violent crime rates on campuses were about one tenth of the U.S. national average from 1997 to 2010 (Birnbaum, 2013, 11), and even less by 2015 (Gius, 2017, Table 1). Covering empirical cases from over a century, another study concluded that the chances of being the random victim of a fatal attack by a stranger or unknown person on a college campus have been, and remain, exceptionally small (Drysdale et al., 2010). However, pervasive media exposure of school shootings may give the opposite impression.

Supporters of campus carry argue that U.S. citizens have a right to self-arm and defend themselves, and that bans on guns violate the Second Amendment (Arrigo \& Acheson, 2016, 121). The premise is that such an inherent right should not be compromised "just because 
someone happens to be on a college campus" (Birnbaum, 2013, 7). Popular rhetoric used by gun-rights advocates is to call gun-free areas "soft targets" or "killing zones" that invite criminals and psychopaths because there are no armed defenders to intervene against them. Regarding higher educational institutions, such rhetoric ignores the fact that most U.S. campuses are already patrolled by the universities' own armed police. The opponents of campus carry argue that colleges and universities should cultivate a learning climate lacking in suspicion, fear, and danger, and that by allowing more guns on campus incidents of violence will escalate rather than diminish (e.g., LaPoint, 2010, 18). Another argument is that academic thought thrives on free and open debate; accordingly, it requires a learning environment free of fear that a stressed fellow student might pull out a gun were a dispute to arise (Birnbaum, 2013, 8). This fear is considered to cause a "chilling effect," which dissuades professors from addressing controversial topics and thereby limits their First Amendment rights of freedom of speech (Wolcott, 2017). Another argument is for academic autonomy, namely that each institution should possess the power to establish its own policy-whatever is deemed suitable - to promote both learning and campus security (Birnbaum, 2013, 8). Arguments claiming institutional autonomy are best justified by providing structures and procedures for scholarly freedom and higher education to flourish (Barendt, 2010).

The public health perspective has most comprehensively been covered in a report by Johns Hopkins University (Webster et al., 2016), which reviews research on the relationship between right-to-carry laws, violent crime, and mass shootings, and discusses the implications of the campus carry policies. This report (Webster et al., 2016) is particularly convincing regarding two matters. First, it shows how research evidence disproves the idea that the presence of guncarrying civilians may reduce the number of active shootings or increase their potential to intervene. By contrast, studies show that right-to-carry firearm laws have not reduced mass shootings or casualties in such shootings; there is also no evidence that "gun-free zones" (or "gun-restricted zones," where only security personnel or police carry guns) facilitate mass shootings or are targeted by shooters (Webster et al., 2016). Moreover, studies have established that legally armed citizens have very rarely intervened successfully to prevent or interrupt mass shootings (see also Short, 2019, 414-417). Second, Webster et al. (2016) draw attention to the risks associated with easier access to guns by students: their still-ongoing mental development is associated with taking more risks, poorer self-control, and the potential for bad, irreversible decisions (Webster et al., 2016, 19). Dangerous age-related behaviors such as binge drinking and drug abuse also elevate the danger of involvement in violent altercations. In addition, because suicidal tendencies are a major issue with students, access to firearms substantially increases the threat, as they comprise the most common method of lethal selfharm in the U.S. (Webster et al., 2016, 3). All in all, Webster et al. (2016) argue that campus carry policies "are unlikely to lead to fewer mass shootings or fewer casualties from those shootings" (ibid., 3). Rather, they conclude that such policies lead to making "far more common acts of aggression, recklessness, or self-harm more deadly," and thus they have "a deleterious impact" on campus safety (ibid., 3). While the public health impact remains to be seen, the first studies on crime, whether based on campus-level (Brandt, 2016; Hayter et al., 2014) or state-level (Gius, 2017) data, show campus carry to have neither a positive nor negative impact on crime rates.

Another well-covered topic involves the perceptions of faculty and students (and to a lesser extent staff) prior to implementing legislation, as assessed by surveys around the U.S. (see also Hassett et al., 2020). The results are univocal: the majority of faculty and students would not have welcomed concealed handguns on their campuses. Thompson, Price, Dake, and Teeple 
(2013) studied the perceptions of faculty at 15 randomly selected state universities in five Great Lakes states. Nearly all of the respondents felt safe on their campuses (98\%) and were not supportive of people carrying concealed handguns there (94\%). Moreover, they perceived that campus carry would create more risks than benefits. When Dahl et al. (2016) ran the same survey questions as Thompson, Price, Dake, and Teeple (2013) among community college faculty in 18 states, they found that $46 \%$ of the respondents owned a firearm, and for more than half of those it was a handgun (Dahl et al., 713). Nevertheless, the key findings were similar: the majority of faculty felt safe on their campuses and were not supportive of having students, faculty, or visitors conceal carry there (ibid., 715). Likewise, in a 2008 survey by Bennett et al. (2012) of faculty at a state university in southeastern Georgia, a substantial majority opposed campus carry legislation. Nor have students tended to favor the idea. When Thompson, Price, Dake, Teeple, Bassler, and Khubchandani (2013b) assessed the perceptions of college undergraduates at 15 public Midwestern universities, the majority (78\%) were not supportive of concealed handguns on campuses, claiming that they would not feel safer if students and faculty carried. Altogether, the studies have shown a prevalently negative attitude toward campus carry among the higher education community. Even many of those who supported concealed carry off-campus were reluctant to have it on-campus (Dahl et al., 2016; Thompson, Price, Dake, \& Teeple, 2013).

The first studies on attitudes in campuses where concealed carry is allowed show that the perceptions have remained predominantly negative, although there is also a substantial minority of campus carry supporters, especially among students (Reimal et al., 2019; Ruoppila \& Butters, 2020). In Kansas, the disapproval was driven by safety concerns, especially around the potential for mishandling of firearms resulting in accidents, but also changes in the campus climate, particularly the dynamics of academic and social interactions (Reimal et al., 2019). A survey conducted on UT Austin undergraduates' opinions two and a half years after implementation showed that most undergraduates thought campus carry was still an important matter (Ruoppila \& Butters, 2020). An interesting finding was that the views of both campus carry supporters and opponents were not black-and-white, with half of the opponents accepting concealed carry off-campus, and a significant part of the supporters preferring stricter limitations on-campus (ibid.). There, too, many students associated campus carry negatively with well-known concerns regarding public health and the learning environment.

In a review article on the campus carry controversy, Arrigo and Acheson (2016) identify several further research topics, including the institutional attempts to find a sensible campusfocused balance between the Second Amendment guarantees of liberty, personal safety concerns, and the interests of the learning environment. They call for studies exploring the culture of higher educational institutions operating with campus carry, including campus gun policy, its perception, and its effects (Arrigo \& Acheson, 2016, 133-134). The current article responds by performing a qualitative, inductively oriented investigation of a single university's policy on campus carry, especially the role and implications of its discretion.

Studies on campus carry implementation and the agency of universities have so far been limited - with the major exception of Aric Short's (2019) study on Texas campus carry legislation. Short $(2019,420-430)$ starts with an overview of how much flexibility the other campus carry states grant to universities in implementation. In most states (Utah, Kansas, Arkansas, Colorado, Georgia) the public universities have very limited authority to regulate firearms on their campuses, in two states (Missippi, Oregon) the current status is unclear, and in two states (Idaho, Wisconsin) the universities have broad authority, to the extent of even 
prohibiting guns on campuses. The agency of universities is primarily noted in the form of some universities' initial refusal to comply, only to be eventually overruled by the courts. In Short's $(2019,429-430)$ perspective, these other states' rigid legal frameworks have done a poor job of balancing the right of license holders to carry firearms on campus with the need to provide individual flexibility to universities. In comparison, he argues, the Texas campus carry law "carves out a unique and effective middle ground" (ibid. 403). The main advantage is that while it has required public universities to allow concealed carry, it has also empowered each institution to design its own firearms policy, based on that school's unique operations and safety concerns. For Short (2019), the law in Texas represents a best practice, an implementation model that other states should follow. Texas law is also the context of a process-oriented implementation study by Opheim and Brittain (2018), which provides an account of how Texas State University officials organized to consult with faculty, staff, and students to exercise the discretion. They describe who was represented in the task force, who was consulted, what kind of data was collected, how public outreach was conducted, what the

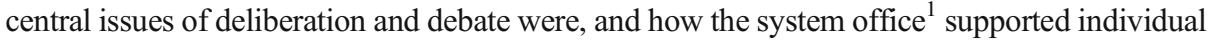
higher education institutions with legal interpretations. Opheim and Brittain (2018) also expose how the regulations adopted at Texas universities differed.

While Short's (2019) focus is on the principles of the Texas law and Opheim and Brittain's (2018) on the discretion process, both note that there are some differences between the universities' gun policy (such as whether the universities allow guns in on-campus dormitories or not) but do not explain the differences or consider their meaning or significance. This study takes the matter further by analyzing the results of discretion, the policy outcomes, and their meaning at the campus level. From a broader higher education policy research perspective, the novel emphasis on implementation is noteworthy as a majority of the literature emphasizes agenda setting and adoption to the exclusion of implementation on individual campuses (e.g., Hearn et al., 2017; McLendon, 2003).

The scholarly background of this paper is implementation studies, widely applied in studies of higher education reforms (e.g., Gornitzka et al., 2005), and the adoption of non-educationrelated policies on campuses (e.g., Moylan et al., 2020). A starting point of the approach is that concretization of policy continues beyond the legislative process. It presumes that not necessarily all fundamental decisions are made during the policy formulation phase, but they may occur also through implementation as organizational actors operationalize policy directives (Hill \& Varone, 2016). The goal congruence between hierarchical actors may involve misalignments and other complexities (e.g., Meyers et al., 2001). For example, they may not simply implement the rules made for them but also seek to make revisions in the process of implementation, taking advantage of their inherent openness and lack of detailed definition (Streeck \& Thelen, 2005). Implementation is thus an integral part of policymaking - with negotiation and bargaining being expected and having an influence on policy outcomes (Hill \& Varone, 2016, 266-272). Through this process, goals may be contested, modified, or even changed; policy emerges in action.

The research question of this paper concerns the role of discretion in the formulation of campus carry policy at The University of Texas at Austin. This matters for identifying the agency of universities in campus carry implementation and, accordingly, in the policy process.

\footnotetext{
${ }^{1}$ A university system is a set of multiple affiliated universities and colleges that are usually geographically distributed. For example, the University of Texas system comprises eight academic institutions and six health institutions.
} 
The explicit change was initiated from above, and complying with the law was required, but a particular point of interest is whether the university officials included some additional goals that influenced the choices and eventually the rules, with significant effects on campus. The work has wider significance for understanding the impact of laws and regulations that clash with ideals of academic autonomy, and which the universities may therefore be hesitant to adopt yet have to implement in one way or another. It also helps to build understanding of the variation in the details of campus carry at the public higher education institutions in Texasand more broadly in the United States.

\section{Discretion at the University of Texas at Austin}

The peculiarity of the Texas law is the discretion it gives to individual universities to create and implement a regulatory plan for concealed carry on campus. The law states three factors that can be considered to "establish reasonable rules, regulations, or other provisions": the "nature of the student population," "specific safety considerations," and "the uniqueness of the campus environment” (Texas Legislature, 2015), but provides no further guidance. In Short's (2019, 454) interpretation, these provisions emphasize that the rules should focus on the actual operations, students, and safety issues relevant to that particular institution. The law is also explicit that the regulations cannot generally prohibit — or have the effect of prohibitingcampus carry (Texas Legislature, 2015).

Under the law, "campus" stands for all land and structures owned or leased by the university (Texas Legislature, 2015). Since 1995, holders of concealed carry licenses in Texas were already allowed to carry their weapons on the outdoor property of universities, including sidewalks, squares, and parking lots (including storing guns in vehicles since 2013). Hence, the new law extended the areas for licensed concealed carry to buildings: classrooms, faculty and staff offices, cafeterias, hallways, lounges, libraries, conference and meeting rooms, and administrative areas. Practically all campus locations are allowed, unless excluded on the basis of state or federal law or university policy (Short, 2019, 447-450). One significant detail worth adding is that the Texas law extended immunity to universities and university employees from civil suits related to damages associated with the actions of a handgun license holder, per Section 411.208 of the Texas government code (Short, 2019, 451-452).

Organizationally, the law gave the power to establish implementing regulations to each university president. As Senate Bill 11 (Texas Legislature, 2015) was passed at the end of May 2015, and the law came into force on August 1, 2016, the universities had 14 months to establish their respective gun policies. Each university quickly formed committees and taskforces to advise their president. The law required consulting with students, faculty, and staff before a president could enact the rules. To varying degrees, universities also invited other interested groups - such as alumni, a community board of advisors, campus security staff, and local law enforcement personnel- to offer input. The political divisions around the issue in Texas (Henson \& Blank, 2016), the fierce opposition by a majority of faculty, staff, and students (e.g., McCann, 2015), and fear-based rhetoric actively used by proponents and opponents (Butters, 2020) did not make the task easy. Finally, the law subjected the rules promulgated by the university president to be reviewed by the board of regents of that university. The regents could amend the regulations by a vote of two-thirds, or the rules went into effect as the presidents wrote them.

UT Austin's policy was ratified in two preparatory committees: the Campus Carry Policy Working Group (University of Texas, 2015), which established the framework, and the 
Campus Concealed Carry Implementation Task Force (University of Texas, 2016a), which defined all the details. The Policy Working Group engaged in the overall public process, including information dissemination and clarification, collecting and considering community feedback, etc.; it also oversaw the expert panel's study, deliberation, and debate. The committees worked to interpret what the law allowed or not, and they worked to specify UT Austin's rules on how carrying was allowed, where guns could be brought (or not), and what kinds of signs were to be used to prohibit them. The established rules were either based on state law (e.g., concealed carry is not allowed where voting is taking place), in accord with legal parallels (e.g., a student health center was excluded due to an existing law about certain other types of hospitals), and even to some extent the university's own discretion (e.g., restricting carrying in private offices by means of giving oral notice, discussed below). The ratified policy was formally published in the Handbook of Operating Procedures (University of Texas, 2016b) and further explicated in a document on the policy and its implementation strategies (University of Texas, 2016c).

\section{Materials and methods}

This study is a part of a transdisciplinary and multi-method research project on the effects of the Texas state campus carry gun legislation conducted by the University of Turku (see Heiskanen, 2020a). The broader project is based on team fieldwork, the collected and analyzed materials including policy documents, semi-structured interviews, focus groups, testimonials, visual materials, and a survey (ibid.). A set of expert and personal semi-structured interviews were conducted in April-May 2018 and February-March 2019, mostly at UT Austin but also at St. Edward's University in Austin. The 28 interviewed individuals included people directly involved in policymaking, implementation, or activism (for and against) surrounding campus carry. The interviewed included administrators, (former and current) students, faculty, and staff. Certain high-profile individuals were identified for interviews, given their experience or role in the campus carry implementation, while others were picked via "snowball" sampling (i.e., after some issues or names had come up in previous interviews or document analysis). The interviews were designed to gather in-depth expert information, yet also allow for the expression of personal viewpoints. The interviews had recurring themes, but the exact questions depended on the role of the respondent. The length of the interviews ranged from 25 to $90 \mathrm{~min}$; the average length being approximately $60 \mathrm{~min}$.

The empirical analysis of this paper is based, first, on the final reports of UT Austin's two preparatory committees (University of Texas, 2015, 2016a) and university policy documents (University of Texas, 2016b, c), which explain the process and results of discretion. Second, it draws especially from five interviews (out of 28): four interviews with people who were members of the Campus Carry Policy Working Group or the Campus Concealed Carry Implementation Task Force, or had been active in further implementation of UT Austin's campus carry policy; one interview was also conducted with a person directly involved with private St Edward's University's security policy and reflected on campus carry in public universities. The function of the interviews of those directly involved in implementation at UT Austin was to obtain firsthand information that could not be read from the published material. These kinds of interview questions included, for instance, "Who decided what kinds of signage there were, and where, and what did the signs say?" or "The working group report recommended gun safes on campuses, but that recommendation was later overturned, so why?" The 
character of the information sought was factual rather than opinions of how the four individuals viewed the process. This is why the small number of interviews is not a significant limitation. The other 23 interviews were useful in identifying details on tensions and conflicts, but did not necessarily include reliable information about discretion relevant to this paper.

The inductively orientated empirical analysis involved the following: first, reading the documents to get a preliminary, overall picture of the policy contents; second, interviewing key people about the process, conflicts, and deliberative policy choices made at the discretion of universities during implementation, and the reasons behind them; and third, conducting content analysis (e.g., Braun \& Clarke, 2006; Cope, 2016) of all the collected material, including coding and organizing the data into different categories and themes. Thematic parsing of the text was used to explicate and conceptualize the policy characteristics. That is, the content of policy papers and interview transcripts were thematically compared, classified, and interpreted in terms of the embedded meanings (e.g., Creswell, 2009). The themes were built inductively, linking the data into increasingly more abstract units of information. Finally, the themes were reviewed, by checking the coherence of the coded data extracts for each theme. As a result, UT Austin's campus carry policy was interpreted to consist of three main ideas (themes). The next section provides an account of how the policy details fit to these three themes. The analysis offers a comprehensive view of the university's discretion and the consequent policy outcomes.

\section{Results: Three principles of UT Austin's campus carry policy}

The result of the content analysis is an analytical separation of three overarching principles of UT Austin's campus carry policy: the differentiation of public and private acts and places, minimizing hazards, and intentional invisibility. None of these are explicitly stated (as such) in the official material, but they provide a coherent frame to understand all the detailed regulations (see University of Texas, 2016b). All decisions mentioned below were made by UT Austin's President Gregory L. Fenves, based on the preparation by the Campus Carry Policy Working Group and the Campus Concealed Carry Implementation Task Force.

The strict differentiation between public and private acts and places regarding campus carry plays out in three different ways. First, carrying is considered a private act, an individual choice, and not the business of others, namely the general public. Within the university area, the gun must be always concealed and hidden (e.g., not visible through clothes). Exposing a firearm on campus is a code violation, and anybody spotting one is supposed to call 911 . By law, only police officers can force someone to reveal whether they are carrying a concealed weapon. Second, the right to carry predominantly concerns places inside university buildings that have a public aspect. A debate arose around classrooms in particular, with many demanding that they be included in the gun-free zones on campus (see Butters, 2021). However, because that would have practically hampered the right of licensed students and teachers to carry and thus violated the principle of the law, no such restriction was made in the university-wide regulations. In areas with a private aspect, consent depends on whose place it belongs to. Thus, university policy grants sole occupiers of private offices the right to exclude people with guns from entering. It should be noted that the same right does not extend to offices with two or more occupants, even if those individuals were to agree on the issue. Third, any gun storage location needs to be private. While concealed carry is allowed in the public areas of UT Austin's student housing, residents can only bring firearms into their own private 
apartments, not (semi-public) student dorms, where they could be exposed to and accessible by others. Apart from private flats, the only other allowed gun storage area on campus is one's own vehicle, which under Texas jurisdiction is considered private space.

The principle of hazard reduction aims at minimizing unintentional harm caused by lawful carrying. Accidental discharges - people firing guns at themselves or others unintentionallywere identified as a major risk. Hence, it was decided that a handgun must be carried in a particular kind of holster. ${ }^{2}$ Another important rule is that a person carrying a concealed firearm must have it "on or about their person at all times" (University of Texas, 2016b), meaning that they should have immediate access to it without needing to move from their place. A concern was that people would have handguns in backpacks or handbags, put them down somewhere, and then go off to do something, with the risk of their firearm falling into the wrong hands. "On or about their person at all times" is meant to convey that people should think about their program and assess accordingly if they want to carry. In particular, this pertains to university sporting facilities, although those facilities are not categorically excluded. As one interviewee noted, "if you are going swimming at Gregory, it's kind of tough to keep the weapon concealed in your Speedo bathing suit, if you know what I mean" (Interview, April 26, 2018). Yet another harm reduction category is prohibition of concealed carry "in areas where the discharge of a firearm might cause great harm," such as high-hazard laboratories and areas containing equipment incompatible with metallic objects (University of Texas, 2016a, 10).

The Campus Carry Policy Working Group debated whether the university should provide gun lockers for staff and students. Some people supported the idea, because in their thinking it might have led to a prohibition of concealed carry in classrooms. However, the idea of lockers was soon abandoned, since they would have increased the amount of time in which guns were handled out in the open, adding to the risk of accidental discharges and also exposing concealed license holders, compromising their privacy (both generally and for potential thieves). Furthermore, this activity would have led to unwanted visibility of campus carry.

The third - and perhaps most interesting - principle is the intentional invisibility of campus carry at UT Austin. Unlike the other two principles, this one cannot be seen in the policy documents. Rather, it was reflected in the expert interviews. As put by a person with a leading role in the Campus Carry Policy Working Group:

One of the things that both the Chancellor of the University and President Fenves said at the outset is that we want the University to look as much like it does now when you are finished. We don't want signs proliferating on this campus. (Interview, April 20, 2018)

The reasoning was that the university premises should be defined by academic substance and practices, not by gun policy. The principle of intentional invisibility is most explicit in terms of the university's signage policy. In physical campus space, restrictions are communicated to licensed carriers in a very subtle manner. Although one finds both explicit and implicit official signs regarding where not to carry, none depict the image of a banned handgun. In addition,

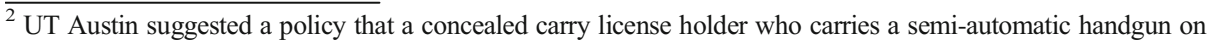
campus must do so without a chambered round of ammunition. However, this motion was struck by the board of regents of the University of Texas System when it reviewed the rules, based on concerns that people may need to unload their guns prior to entering a building on campus, which could lead to unsafe situations, such as an accidental discharge. The board made no other changes to the policies submitted by all UT institutions (The University of Texas System, 2016).
} 
there are some areas where restrictions apply (always or during certain times), but signage is not applied. The three categories are presented in Table 1.

Explicit signage is provided mostly in locations where concealed carry is prohibited at all times or where a particular activity is excluded by the Texas penal code. In most cases, one finds the Section 30.06 sign, which includes statutory text in English and Spanish. The Section 30.06 sign and the Section 411.204 ("51\%") sign, which bans handguns from the premises of businesses selling alcohol for onsite consumption, are visible throughout Texas, not only in campus areas. The statutory text on the Section 30.06 sign is what makes it official. However, in the version seen most often elsewhere in Texas, the text is accompanied with a "no guns" symbol (red circle and slash over a pistol). Significantly, UT Austin has specifically chosen to not have any images of guns in the campus area.

Implicit signage is applied in connection with two kinds of temporary activities, during which campus premises are excluded from guns, based on Texas penal code. This includes sites where pre-K-12 school-sponsored activities, such as field trips, may be taking place. When this is happening, the carrying of handguns is prohibited at that particular location. Likewise, carrying a handgun is prohibited on the premises of a polling place on the day of an election or while early voting is in progress. On both occasions, the posted signage indicates only the ongoing activity, and the concealed carrier is assumed to be able to understand, by inference, the appropriate course of conduct. The obligatory training course, which all concealed carry permit holders are supposed to have taken, includes studying the places where concealed carry is not allowed. Hence, a licensed carrier should be able to figure out what the signs imply, but it is questionable whether they do. The university considers the possible limitations in assumed understandings a state-level training problem, however, not a matter that is related to university policy.

Table 1 Types of signage for UT Austin areas where concealed carry of handguns is prohibited

\begin{tabular}{|c|c|c|}
\hline Explicit signage & Implicit signage & No signage \\
\hline $\begin{array}{l}\text { - Areas for which state or federal } \\
\text { law, licensing requirements, or } \\
\text { contracts require exclusion } \\
\text { - Areas of formal hearings } \\
\text { - Grounds or buildings where } \\
\text { "Campus Program for Minors" } \\
\text { is conducted } \\
\text { - High-hazard laboratories } \\
\text { - Patient-care areas } \\
\text { - Ticketed sporting events } \\
\text { - Ticketed events at the Frank } \\
\text { Erwin Center } \\
\text { - The premises of any } \\
\text { government court or offices } \\
\text { utilized by the court } \\
\text { - UT Tower observation deck and } \\
\text { its immediate areas secured by } \\
\text { UTPD } \\
\text { - Businesses deriving } 51 \% \text { or } \\
\text { more of their income from the } \\
\text { sale of alcoholic beverages }\end{array}$ & $\begin{array}{l}\text { - Sites of pre-K-12 } \\
\text { school-sponsored activities } \\
\text { - The premises of a polling place } \\
\text { on the day of an election or } \\
\text { while early voting is in progress }\end{array}$ & $\begin{array}{l}\text { - Single-occupant office, at the occu- } \\
\text { pant's discretion: by oral notification } \\
\text { only } \\
\text { - Student rooms in on-campus residence } \\
\text { halls } \\
\text { - High school, collegiate, or professional } \\
\text { sporting events or inter-scholastic } \\
\text { events: written notice by organizers }\end{array}$ \\
\hline
\end{tabular}

Source: University of Texas, 2016b (HOP 8-1060) 
A lot of people said the training wasn't sufficient enough. We kind of backed out of that and said, "That's not our problem. If you feel the training is insufficient, you need to talk to your state representatives and get them to change the law, because that law says to get licensed in the state of Texas, you have to do these things. (Interview, April 26, 2018)

Granting the sole occupiers of private offices the right to exclude people with guns from entering was considered a major problem by those working on the policy, as they presumed that the campus area would become full of those signs.

Because we did not want a situation where [...] when you walk down the hall of any building where there are offices, someone would see a gun sign after a gun sign after a gun sign after a gun sign. [...] What came to my mind immediately was, we are recruiting somebody to join our faculty and, walking around, what do they see about this campus? Guns. Every office they go to, they would see a sign, because almost every faculty member would put such a sign up if they could. That would so overemphasize the importance of this issue on this campus. It would make it seem like this was the predominant thing that this campus was about is guns. We just thought that was a terrible idea. (Interview, April 20, 2018)

The deliberate choice to avoid any visible signs had a major impact when choosing the way in which single-occupiers of offices could communicate the gun policy of their private space, namely by oral notification only. As was explained by a person active in the working group:

Until we came up with the idea for oral notification as opposed to written notification, which the statute does allow, we thought that was a major stumbling block to allowing people to exclude handguns. And then we had the insight, "Wait a second, we don't have to do it by written signs. We can do it under the statute simply by oral notification. Okay, we can do this." (Interview, April 20, 2018)

The oral notification regarding exclusion of guns from private offices was presumably an innovation made at UT Austin but later applied by a number of other universities. The faculty heavily criticized the decision. Furthermore, what the university leadership did not see coming was that their policy would inspire a number of critical faculty members to add signs of their own design, advocating for the no-gun policy or requesting a person to ask for their gun policy, in order to provide the official oral notice. The carnivalesque signage is still a visible feature in UT Austin hallways, although much more widespread in humanities and social sciences buildings than in the natural sciences (see Heiskanen, 2020b). Personal signage is considered a freedom of speech issue. As one interviewee noted, "people express their views and that's part of being on a campus" (Interview, April 20, 2018).

Because the university does not proactively bring up campus carry in any situation, the intentional invisibility extends also to communications policy. The protocol of the university's central communications office is "a very low-profile approach" (Interview, March 4, 2019). For instance, the law is not mentioned as part of orientation for new students, even in the information distributed to them.

We don't go out and actively promote this. It's on a website. If you want to find the information, you can find it. But you have to look for it. (Interview, March 4, 2019) 
All in all, the intentional invisibility implies a wish to keep campus carry out of sight, distance non-carriers (the majority) from the issue, and direct the state-mandated communication to licensed carriers only, using a code language that they are supposed to recognize. This was a deliberate choice. An expert actively involved in the Campus Concealed Carry Implementation Task Force put it as follows:

We thought there was no sense to alarm the normal community, but you had to alert the concealed carrier [about] what he could do and what he couldn't do. (Interview, April 26, 2018)

The university's central administration feels that it has accomplished the mission of making campus carry a "non-issue" (Interview, March 4, 2019). In their thinking, the change has had very little impact, and people would have forgotten it already had not the lawsuit filed by three UT Austin professors (lost, appealed, and then lost again) kept the issue in the media spotlight (e.g., Choi, 2018).

\section{Conclusions and discussion: Out of sight, out of mind?}

This article has shed light on how a campus carry policy was implemented at a major state university, examining its modification of the policy. The study has a broader significance, for as campus carry legislation is both spreading to an increasing number of states and becoming more detailed, the questions concerning implementation remain important, and the Texas law has been even suggested as a best practice (Short, 2019). There have also been calls for research to explore the realities of higher educational institutions operating with campus carry (Arrigo \& Acheson, 2016, 133-134). In Short's (2019) perspective, the Texas law, which requires all public higher education institutions to allow concealed carry but empowers them to carve their own firearms policy, effectively balances between the competing rights and interests, providing a "sane" and effective middle ground. While the customized form of implementation certainly is a significant improvement over imposing a rigid framework, it is not quite a "middle ground" in the debate, which has considered the essential question of whether allowing licensed civilians to bring (concealed) handguns on campuses is reasonable in the first place (Arrigo \& Acheson, 2016; Birnbaum, 2013; Webster et al., 2016).

The research question of this paper concerned the role of discretion in formulating the campus carry policy at The University of Texas at Austin. There was major reluctance in its academic community toward accepting the law, but as a state university it had no choice but to implement it. The analysis drew from the scholarly viewpoint that policymaking continues in the implementation phase through revising and making precise redefinitions that have influences on the policy outcomes (e.g., Hill \& Varone, 2016). For the wider implementation literature concerning higher education (e.g., Gornitzka et al., 2005), the work offers an interesting example of how the policy being "unwanted" was reflected in implementation, thereby maintaining the agency of the university. For higher education policy research (e.g., Hearn et al., 2017; McLendon, 2003), it concretizes how implementation may matter even at the level of individual campuses.

As the analysis established, the overarching principles of UT Austin's campus carry policy have been differentiation between public and private acts and places, minimizing hazards, and intentional invisibility. At the heart of all three principles is the university's own policy goal to keep out of sight and unexposed the reality that some people on campus are carrying guns; this 
includes the guns themselves and the whole campus carry phenomenon. UT Austin fully accomplishes the law, but through its own established policy, it has sought to hide that fact and thus obscure the issue from everyday campus life. The administration's aim for the university to look virtually the same was consciously followed in the tailoring of the implementation. Very few places have signs that explicitly hint at campus carry - and none of them have a picture of gun (i.e., a "no guns" symbol with a red circle and slash), which commonly accompanies the statutory text elsewhere in Texas. The biggest step in preventing images of (no) guns was denying the single-occupiers of private offices this way of communicating their personal policy, allowing it by oral notification only. Another outstanding measure to hide the phenomenon has been the practice of not communicating it at all to newcomers at the university. Campus carry is nowhere seen in orientation for new students, training videos for armed intruder attacks (obligatory for faculty and staff), and so forth. All the information is neatly found on the university website, but no one is invited to look at it. The university leadership considers campus carry a "non-issue" that is better forgotten. However, the survey results showing most undergraduates think it is still an important issue (Ruoppila \& Butters, 2020) calls this approach into question.

How unique, then, is UT Austin's additional policy goal of hiding campus carry? It is apparent that while the law was the same for all public universities in Texas, the spirit of implementation was not. In light of Short (2019) and Opheim and Brittain (2018), the main differences between the custom rules of Texas universities include whether there are handgun lockers at campuses, whether gun storage is allowed in oncampus housing, whether private offices can be excluded (and by written or oral notice), and rules regulating carrying in other than learning or residential spaces. Moreover, these differences appear also between universities in the same system. While there is not enough information for a direct comparison, already these factors suggest significant differences in public exposure to firearms on various campus grounds, based on how explicit the signs are prohibiting concealed carrying in delineated zones, or how gun storage lockers (if they exist on campus) are communicated. Hence, institutional and policy differences in campus carry not only exist between states but also between single universities.

From a pragmatic point of view, and given the limited options it had, UT Austin's desire to avoid controversy and possible liability by keeping campus carry out of sight is understandable. However, the implications for the campus community are not unproblematic. First, the campus community's knowledgeability of the issue depends on people's own activity, information sourcing, social networks, and interests. Many may not be aware that some teachers, staff, and students are carrying handguns on campus, or they have very limited knowledge of the practice. While the university is supporting active involvement in society, including debates and new perspectives on controversial issues, it is remarkable that this subject, which has implications for maneuvering on campus, is overlooked.

Second, given a potential situation with compromised safety, including one or more exposed guns, even elementary knowledge of the operational environment would be beneficial for community members. While telling the difference between a malicious intruder, a nervous student, a licensed carrier, or a combination of these is predominantly a challenge for armed law enforcement, such as campus police, it also concerns the other people there. Campus policy and training in such occasions would come in handy, instead of hiding the fact that there are guns and carriers with 
potentially different motivations. ${ }^{3}$ In addition, as Webster et al. (2016) emphasize, the increased level of gun possession by the student population is a safety risk that requires deliberate safety measures. From a health perspective, it is somewhat inconsistent that UT Austin's messaging is very visible in terms of having a smoke-free campus or offering afterhours rideshares and companions to move around campus more safely during less populated times of day, but the university keeps quiet on guns.

Third, it is not flattering for the university leadership that the controversial issue is proclaimed a "non-issue" rather than accepted similar to any other prolonged political conflict in society. The fact that the legislation has been passed and implemented does not make the issue (as discussed by Birnbaum, 2013; Arrigo \& Acheson, 2016) outdated or disappear; instead, campus carry remains an unresolved source of conflict (Ruoppila \& Butters, 2020). Although this is not currently for the university to solve, even by significantly modifying its own campus carry policy, the openness and discussions of potential consequences such as the "chilling effect," as well as the campus security policy, could be reconsidered. Texas law shields the university from legal recourse around any damages associated with the actions of a handgun license holder (Short, 2019, 451). If a major incident were to occur, and it ended up being more severe because the university had kept campus carry hidden, it is doubtful that the opponents of the policy—including donors, families, and even certain segments of the media—would have much mercy.

Funding Open access funding provided by University of Turku (UTU) including Turku University Central Hospital. Academy of Finland, grant number 310568.

Availability of data and material The policy documents are public, the references are provided in the manuscript. The interview transcripts are in possession of the author and archived by John Morton Center for North American Studies at the University of Turku, but not open to public as agreed in the consent signed by the interviewees and the center representative.

Code availability Not applicable.

\section{Declarations}

Conflict of interest The author declares not to have any conflict of interest.

Open Access This article is licensed under a Creative Commons Attribution 4.0 International License, which permits use, sharing, adaptation, distribution and reproduction in any medium or format, as long as you give appropriate credit to the original author(s) and the source, provide a link to the Creative Commons licence, and indicate if changes were made. The images or other third party material in this article are included in the article's Creative Commons licence, unless indicated otherwise in a credit line to the material. If material is not included in the article's Creative Commons licence and your intended use is not permitted by statutory regulation or exceeds the permitted use, you will need to obtain permission directly from the copyright holder. To view a copy of this licence, visit http://creativecommons.org/licenses/by/4.0/.

\footnotetext{
$\overline{3}$ St. Edward's University, a private university in Austin which opted out of campus carry, instead established a campus resilience unit to run preventive safety measures, such as emergency planning, training, and exercises for faculty, staff, and students. One concern was an active shooter: how to recognize the threat, build protective barriers to slow down the attacker, and defend if the situation so required. The emphasis was on "denying" the attacker access, in order to win time for law enforcement to do its task. Because carrying firearms was banned on the whole campus (licensed carriers included), the campus police there have a major advantage in identifying a person with a firearm as a violator in any situation. As the interviewed security official observed, "if we were to have an armed intruder [...], I would not want to be running around campus with a gun when law enforcement got here" (Interview, May 2, 2018).
} 


\section{References}

Arrigo, B. A., \& Acheson, A. (2016). Concealed carry bans and the American college campus: A law, social sciences, and policy perspective. Contemporary Justice Review. https://doi.org/10.1080/10282580.2015. 1101688 .

Barendt, E. (2010). Academic freedom and the law: A comparative study. Hart Publishing.

Bennett, K., Kraft, J., \& Grubb, D. (2012). University faculty attitudes toward guns on campus. Journal of Criminal Justice Education. https://doi.org/10.1080/10511253.2011.590515.

Birnbaum, R. (2013). Ready, fire, aim: The college campus gun fight. Change: The Magazine of Higher Learning. https://doi.org/10.1080/00091383.2013.812462.

Boots, D. P., Bihari, J., \& Elliott, E. (2009). The state of the castle: An overview of recent trends in State Castle doctrine legislation and public policy. Criminal Justice Review. https://doi.org/10.1177/0734016809332095.

Brandt, J.R. (2016). Does Concealed Handgun Carry Make Campus Safer? A Panel Data Analysis of Crime on College and University Campuses. Master of Public Affairs thesis, The University of Texas at Austin. https://repositories.lib.utexas.edu/handle/2152/45730

Braun, V., \& Clarke, V. (2006). Using thematic analysis in psychology. Qualitative Research in Psychology. https://doi.org/10.1191/1478088706qp063oa.

Butters, A. M. (2020). Beyond argumentum in terrorem: The contested rhetoric of campus carry. Journal of American Studies. https://doi.org/10.1017/S0021875820001395.

Butters, A. M. (2021). Fear in the classroom: Campus carry at The University of Texas at Austin. Texas Education Review, https://doi.org/10.26153/tsw/11418

Chase, A. (2015). Legislature ignores police voices with passage of campus carry. The Daily Texan, October 15. https://hedailytexan.com/2015/10/15/legislature-ignores-police-voices-with-passage-of-campus-carry

Choi, M. (2018). Guns chill free speech, UT-Austin professors will argue at federal appeals court. The Texas Tribune, July 11. https://www.texastribune.org/2018/07/11/ut-austin-professors-argue-campus-carry-chillsfree-speech/

Cope, M. (2016). Coding and analyzing qualitative data. In I. Hay (Ed.), Qualitative research methodologies for human geographers (4th ed., pp. 373-393). Oxford University Press.

Creswell, J. W. (2009). Research design: Qualitative, quantitative, and mixed methods approaches (3rd ed.). Sage Publications.

Dahl, P. P., Bonham Jr., G., \& Reddington, F. P. (2016). Community college faculty: Attitudes toward guns on campus. Community College Journal of Research and Practice. https://doi.org/10.1080/10668926.2015. 1124813.

District of Columbia v. Heller (2008). U.S. Supreme Court, 554 U.S. 570. https://supreme.justia.com/cases/ federal/us/554/570/

Drysdale, D., Modzeleski, D., \& Simons, A. (2010). Campus attacks: Targeted violence affecting institutions of higher education. Washington, DC: US Secret Service, US Department of Homeland Security, Office of Safe and Drug-Free Schools, US Department of Education, and Federal Bureau of Investigation, US Department of Justice. http://www.fbi.gov/stats-services/publications/campus-attacks Accessed February 15, 2020.

Gius, M. (2017). Campus crime and concealed carry laws: Is arming students the answer? The Social Science Journal. https://doi.org/10.1016/j.soscij.2018.04.004

Gornitzka, A., Kogan, M., \& Amaral, A. (Eds.). (2005). Reform and change in higher education. Analysing policy implementation. Springer.

Harnisch, T.L. (2008). Concealed weapons on state college campuses: In pursuit of individual liberty and collective security. American Association of State Colleges and Universities (AASCU): A Higher Education Policy Brief. http:/www.aascu.org/workarea/downloadasset.aspx?id=4545 Accessed February 15, 2020.

Hassett, M. R., Bitna, K., \& Chunghyeon, S. (2020). Attitudes toward concealed carry of firearms on campus: A systematic review of the literature. Journal of School Violence. https://doi.org/10.1080/15388220.2019. 1703717

Hayter, J. K., Shelley, G. L., \& Stevenson, T. P. (2014). Right-to-carry and campus crime: Evidence from the not-so-wild-west. Libertarian Papers, 6(1), 1-20.

Hearn, J. C., McLendon, M. K., \& Linthicum, K. C. (2017). Conceptualizing state policy adoption and diffusion. Higher education: Handbook of theory and research, 309-354.

Heiskanen, B. (2020a). Forum: Perceiving security and insecurity: The campus carry law in Texas. Journal of American Studies. https://doi.org/10.1017/S0021875820001383

Heiskanen, B. (2020b). Un/seeing campus carry: Experiencing gun culture in Texas. European Journal of American Studies. https://doi.org/10.4000/ejas.15817 
Henson, J., \& Blank, J. (2016). Reviewing Texas attitudes toward campus carry as law goes into effect. The Texas Politics Project at the University of Texas at Austin, August 1. https://texaspolitics.utexas.edu/blog/ reviewing-texas-attitudes-toward-campus-carry-law-goes-effect Accessed 10 February 2021.

Hill, M., \& Varone, F. (2016). The public policy process (7th ed.). Routledge.

Johnson, D. R., \& Zhang, L. (2020). Intrastate and interstate influences on the introduction and enactment of campus carry legislation, 2004-2016. Educational Researcher. https://doi.org/10.3102/0013189X20902121.

LaPoint, L. A. (2010). The up and down battle for concealed carry at public universities. Journal of Student Affairs (Colorado State University), 19, 16-21.

Lott, J.R., \& Wang, R. (2020). Concealed carry permit holders across the United States: 2020 (September 21, 2020). Report from the Crime Prevention Research Center, https://doi.org/10.2139/ssrn.3703977

McCann, M. (2015). Campus carry pushback heats up. The Austin Chronicle, 30 October. https://www. austinchronicle.com/news/2015-10-30/campus-carry-pushback-heats-up/

McLendon, M. K. (2003). The politics of higher education: Toward an expanded research agenda. Educational Policy, 17(1), 165-191.

Meyers, M. K., Riccucci, N. M., \& Lurie, I. (2001). Achieving goal congruence in complex environments: The case of welfare reform. Journal of Public Administration Research and Theory. https://doi.org/10.1093/ oxfordjournals.jpart.a003498.

Moylan, C. A., Hammock, A., \& Carlson, M. L. (2020). In the eye of the reformer: Higher education personnel perspectives on campus sexual assault policy implementation. Journal of School Violence. https://doi.org/10. $1080 / 15388220.2020 .1728285$.

National Conference of State Legislatures. (2019). Guns on campus: Overview (updated November 1, 2019). http://www.ncsl.org/research/education/guns-on-campus-overview.aspx Accessed February 12, 2021.

Opheim, C., \& Brittain, V. (2018). Guns on campus: Implementing campus carry. Journal of Higher Education Management, 32(2), 167-179.

Pew Research Center (2017). America's Complex Relationship with Guns. Report. June 22. http://www. pewresearch.org/fact-tank/2017/06/22/key-take-aways-on-americans-views-of-guns-and-gun-ownership/ Accessed February 15, 2020.

Reimal, E., Esthappan, S., Thompson, P.S., \& Jagannath, J. (2019). Guns on college campuses. Students' and University officials' perceptions of campus carry legislation in Kansas. The Urban Institute, Justice Policy Center.

Ruoppila, S., \& Butters, A. (2020). Not a "nonissue": Perceptions and realities of campus carry at the University of Texas at Austin. Journal of American Studies. https://doi.org/10.1017/S0021875820001425

Short, A. (2019). Sane gun policy from Texas: Blueprint for balanced state campus carry laws. Northeastern University Law Review, 11(2), 401-473.

Sparber, S. (2021). Texans can carry handguns without a license or training starting Sept. 1, after Gov. Greg Abbott signs permitless carry bill into law. The Texas Tribune, June 16. https://www.texastribune.org/2021/ 06/16/texas-constitutional-carry-greg-abbott/

Spitzer, R. J. (2015). Guns across America: Reconciling gun rules and rights. Oxford University Press.

Streeck, W., \& Thelen, K. (2005). Introduction: Institutional change in advanced political economies. In W. Streeck \& K. Thelen (Eds.), Beyond continuity: Institutional change in advanced political economies (pp. 139). Oxford University Press.

Texas Legislature (2015). Senate Bill 11. https://capitol.texas.gov/tlodocs/84R/billtext/pdf/SB00011F.pdf Accessed February 15, 2020.

The University of Texas System (2016). UT system board of regents reviews campus carry plans. https://www. utsystem.edu/news/2016/07/13/ut-system-board-regents-reviews-campus-carry-plans Accessed February 10, 2021.

Thompson, A., Price, J. H., Dake, J., \& Teeple, K. (2013a). Faculty perceptions and practices regarding carrying concealed handguns on university campuses. Journal of Community Health. https://doi.org/10.1007/s10900012-9626-0.

Thompson, A., Price, J.H., Dake, J.A., Teeple, K., Bassler, S., Khubchandani, J., et al. (2013b). Student perceptions and practices regarding carrying concealed handguns on university campuses. Journal of American College Health. https://doi.org/10.1080/07448481.2013.799478

University of Texas (2015). Campus carry policy working group final report (December 2015). https://utexas. app.box.com/v/CCWorkingGroup-FinalReport Accessed February 15, 2020.

University of Texas (2016a). Campus concealed carry implementation task force report (July 25, 2016). https:// utexas.app.box.com/v/cc-implementation-report Accessed February 15, 2020.

University of Texas (2016b). Handbook of operating procedures 8-1060: Campus concealed carry (effective August 1, 2016). https://policies.utexas.edu/policies/campus-concealed-carry Accessed February 15, 2020.

University of Texas (2016c). Campus carry policies and implementation strategies (September 1, 2016). https:// utexas.app.box.com/v/campus-carry-report Accessed February 15, 2020. 
Watkins, M. \& Conway, M. (2016). Only one private Texas university adopting campus carry. The Texas Tribune, July 29. https:/www.texastribune.org/2016/07/29/all-one-private-university-texas-are-opting-out$\mathrm{ca} /$

Webster, D.W., Donohue, J.J. III, Klarevas, L., Crifasi, C.K., Vernick, J.S., Jernigan, D., et al. (2016). Firearms on college campuses: research evidence and policy implications. Johns Hopkins University, Bloomberg School of Public Health \& Center for Gun Policy and Research.

Winkler, A. (2011). Gunfight: The Battle over the right to bear arms in America. W.W. Norton.

Wolcott, C.M. (2017). The chilling effect of campus carry: How the Kansas campus carry statute impermissibly infringes upon the academic freedom of individual professors and faculty members. University of Kansas Law Review, https://doi.org/10.17161/1808.25573

Yamane, D. (2017). The sociology of U.S. gun culture. Sociology Compass, https://doi.org/10.1111/soc4.12497

Publisher's note Springer Nature remains neutral with regard to jurisdictional claims in published maps and institutional affiliations. 